\title{
Diagnosis of cutaneous tuberculosis in biopsy specimens by PCR and Southern blotting
}

\author{
E Quirós, M C Maroto, A Bettinardi, I González, G Piédrola
}

\begin{abstract}
Aims-To evaluate the use of a gene amplification and hybridisation method for detecting mycobacterial nucleic acid as a possible diagnostic method for cutaneous tuberculosis infection.

Methods-Biopsy specimens from 20 patients with various skin conditions of possible tuberculous aetiology were studied. Six patients had ulcerative nodules, seven lupiform lesions, two non-necrotic granulomas, one scrofulous lichen, one impetigo, one erythematosus lesions, one warty lesions, and one suspected tuberculous lipoma. Biopsy specimens were stained using Ziehl-Neelsen stain and cultured in Lowenstein-Jensen medium. DNA was extracted and then amplified by PCR using primers specific for the $M y c o-$ bacterium tuberculosis complex. Specificity was confirmed by Southern blotting.

Results-Of the specimens, $30 \%$ were positive for mycobacteria on staining with Ziehl-Neelsen stain, $60 \%$ were culture positive and $85 \%$ PCR positive. Only $35.2 \%$ of specimens were positive with all three techniques. A further $32.5 \%$ were both culture and PCR positive. All PCR negative samples were also negative when cultured or stained with Ziehl-Neelsen stain. Of the PCR positive specimens, $29.4 \%$ were negative when cultured or stained.

Conclusions-PCR, using suitable primers, is an efficient and sensitive method for the diagnosis of cutaneous tuberculosis.

(F Clin Pathol 1996;49:889-891)
\end{abstract}

Department of

Microbiology, Medical

School, University of

Granada, Granada,

Spain

M C Maroto

I González

G Piédrola

Combiotec, Brescia,

Italy

E Quirós

A Bettinardi

Correspondence to:

Dr M C Maroto,

Department of Microbiology,

School of Medicine,

Avenida de Madrid, 11 ,

18012 Granada, Spain.

Accepted for publication 16 April 1996
Keywords: cutaneous tuberculosis, PCR, Southern blotting.

Cutaneous conditions caused by Mycobacterium tuberculosis are relatively rare. Clinical expression may be exogenous or endogenous, the latter occurring when a tubercle lying beneath the skin releases the infection into the lymphatic system or blood stream.'

The clinical features are influenced by the virulence of the bacillus, the immunological state of the patient and non-specific factors such as age, race, general state of health, etc. ${ }^{23}$ Given this clinical heterogeneity and the difficulties in diagnosing this condition (slow bacterial growth, ineffectiveness of antibody investigation and limited value of intradermoreaction), the need for further diagnostic markers of infection is evident.

\section{Methods}

The study population comprised 20 patients with diverse skin conditions of possible tuberculous aetiology. Six patients had ulcerative lesions, seven lupiform lesions, two nonnecrotic granulomas, one scrofulous lichen, one impetigo, one erythematosus lesions, one warty lesions, and one tuberculous lipoma (table 1). Four patients were HIV positive intravenous drug users (cases $2,10,18$, and 20 ). Only one patient (case 18) presented with active tuberculosis and another (case 10) cohabited with a partner who had presented with disseminated tuberculosis. Cases 2, 4, 5, 6 , and 9 had painful axillary and inguinal nodules.

A skin biopsy specimen of the area affected was obtained from all patients, fixed in formalin and embedded in paraffin wax. Sections were stained with Ziehl-Neelsen stain and cultured in Lowenstein-Jensen medium (Becton Dickinson, Meylan Cedex, France), as described previously. For PCR and Southern blotting, sections $(6 \mu \mathrm{m})$ were cut and dewaxed in xylene at $55^{\circ} \mathrm{C}$ for 10 minutes, centrifuged, washed with absolute alcohol, and then lyophilised. Prior to DNA amplification, the lyophilised samples were digested with a buffer containing $50 \mathrm{nmol}$ Tris, $1 \mathrm{nmol}$ acetic acid, $0.5 \%$ Tween $20(\mathrm{pH} 8.5)$, and $200 \mathrm{ng} / \mathrm{ml}$ proteinase $\mathrm{K}$ for four hours at $55^{\circ} \mathrm{C}$ with gentle shaking.

\section{POLYMERASE CHAIN REACTION}

After proteolytic digestion, samples were subjected to enzymatic gene amplification by PCR. The reaction mixture comprised 5-10 $\mu 1$ sample, 2 units Taq DNA polymerase (Promega, Madison, Wisconsin, USA), 50 pmol of each primer (positive primer: 5'-CAA-GGCTTC-AAT-TCC-GGT-GAT-GCC- 3'; negative primer: 5'-TGG-TCC-GGT-TCA-TAC-TCGGGC-TGG-3') and $60 \mathrm{nmol}$ of each dNTP in PCR buffer (10 nmol Tris (pH 8.3), $50 \mathrm{nmol}$ $\mathrm{KCl}, 4 \mathrm{nmol} \mathrm{MgCl}_{2}$ ), made up to $60 \mu \mathrm{l}$. PCR conditions were as follows: $95^{\circ} \mathrm{C}$ for five minutes, $94^{\circ} \mathrm{C}$ for one minute and $70^{\circ} \mathrm{C}$ for one minute for 40 cycles.

The primers chosen amplify $M$ tuberculosis complex DNA, including $M$ tuberculosis, $M$ africanum, and $M$ bovis DNA, but not that of other mycobacterial species-for example, $M$ avium, $M$ chelonae, $M$ paratuberculosis, $M$ fortuitum, $M$ kansasii, $M$ marinum, $M$ terrae, $M$ szulgai, $M$ xenopi, $M$ scrofulaceum, and $M$ simiae.

The specificity of PCR amplification was confirmed by running an aliquot of each PCR product on $2 \%$ agarose gels. PCR products 
Table 1 Clinicopathological details of the patients studied

\begin{tabular}{|c|c|c|c|c|c|}
\hline $\begin{array}{l}\text { Case } \\
\text { number }\end{array}$ & Lesion & Case history & $A F B$ & Culture & $P C R$ \\
\hline 1 & Recurrent ulcerative nodule on leg & Leg fracture one year previously & - & + & + \\
\hline 2 & Non-necrtotic granuloma on forearm & Painful axillary nodules; HIV positive & - & - & - \\
\hline 3 & Recurrent ulcerative nodule on knee & Meniscus operation two years previously & - & - & + \\
\hline 4 & Non-necrtotic granuloma on shoulder & Painful neck and axillary nodules & - & + & + \\
\hline 5 & Ulcerative nodule on arm & Painful axillary nodules & + & + & + \\
\hline 6 & Ulcerative nodules on arm & Painful axillary nodules & - & - & - \\
\hline 7 & Scrofulous lichen on thigh & & - & - & - \\
\hline 9 & Impetigo on elbow & Painful axillary nodules & - & + & + \\
\hline 10 & Lupus-like lesions on legs & $\begin{array}{l}\text { Intravenous drug user; HIV positive; partner with disseminated } \\
\text { tuberculosis }\end{array}$ & - & - & + \\
\hline 11 & Lupus vulgaris on nose & & - & - & + \\
\hline 12 & Lupus vulgaris on earlobe & & + & + & + \\
\hline 13 & Ulcerative nodule on arm & & - & + & + \\
\hline 14 & Lupus vulgaris on leg & & - & - & + \\
\hline 15 & Lupus vulgaris on back & & - & + & + \\
\hline 16 & Tuberculous lipoma on face & & - & + & + \\
\hline 19 & Lupus vulgaris on ear & & + & + & + \\
\hline 20 & Warty lesion & $\begin{array}{l}\text { HIV positive; history of pulmonary tuberculosis; diagnosed } \\
\text { subsequently with Leishmaniasis }\end{array}$ & - & - & - \\
\hline
\end{tabular}

AFB $=$ acid-fast bacillus.

Table 2 Results of staining, culture and PCR in skin samples studied. Results are expressed as $n(\%)$

\begin{tabular}{lc}
\hline Method & Positive \\
\hline AFB smear & $6(20)$ \\
Culture & $12(60)$ \\
PCR & $17(85)$ \\
\hline
\end{tabular}

$\mathrm{AFB}=$ acid-fast bacillus.

( 285 base pair bands) were visualised by staining with ethidium bromide and viewing under ultraviolet light.

The usual precautions were taken to prevent cross contamination, and positive and negative controls were included in each PCR run. The positive control comprised DNA from a patient with known $M$ tuberculosis infection (confirmed by culture) and was run at 10, 5 and $1 \mu \mathrm{g} / \mathrm{ml}$. The negative controls comprised DNA from $M$ avium, DNA from $M$ paratuberculosis, a lymph node biopsy specimen (positive culture) from a patient infected with $M$ scrofulaceum, a biopsy specimen of a $M$ leprae lesion, tissue samples from patients with sarcoidosis, and tissue from a patient with lupus erythematosus.

\section{SOUTHERN BLOTTING}

Amplified samples were run on agarose gels and transferred to Hyband $\mathrm{N}+$ nylon filters (Amersham, Little Chalfont, UK), according to the manufacturer's instructions. Filters were incubated for one hour at $58^{\circ} \mathrm{C}$ in prehybridisation solution containing $5 \times$ SSC, $5 \times$ Denhardt's solution, $0.5 \% \mathrm{SDS}$, and $100 \mathrm{ng} / \mathrm{ml}$ denatured salmon sperm DNA, then hybridised overnight at $58^{\circ} \mathrm{C}$ with a ${ }^{32} \mathrm{P} 5^{\prime}$ end labelled

Table 3 Comparison of results obtained on staining, culture and PCR

\begin{tabular}{|c|c|c|c|c|}
\hline & \multicolumn{2}{|c|}{ AFB smear positive $(n=6)$} & \multicolumn{2}{|c|}{ AFB smear negative $(n=14)$} \\
\hline & $\begin{array}{l}\text { Culture positive } \\
n(\%)\end{array}$ & $\begin{array}{l}\text { Culture negative } \\
n(\%)\end{array}$ & $\begin{array}{l}\text { Culture positive } \\
n(\%)\end{array}$ & $\begin{array}{l}\text { Culture negative } \\
n(\%)\end{array}$ \\
\hline $\begin{array}{c}\text { PCR positive } \\
(\mathrm{n}=17)\end{array}$ & $6(35.2)$ & & $6(35.2)$ & $5(29.4)$ \\
\hline $\begin{array}{l}\text { PCR negative } \\
\quad(\mathrm{n}=3)\end{array}$ & & & & $3(100)$ \\
\hline Total & 6 & & 6 & 8 \\
\hline
\end{tabular}

AFB = acid-fast bacillus. (about $1 \times 10^{6} \mathrm{cpm} / \mathrm{ml}$ ) internal oligonucleotide probe (5'-TCA-GCG-GAG-AGC-CGGTGA-ACT-TGT-C-3').

Filters were washed twice for 15 minutes each at room temperature in $2 \times$ SSC and $2 \%$ SDS, and then for 60 minutes at $58^{\circ} \mathrm{C}$ in $0.2 \%$ SSC and $0.2 \%$ SDS and autoradiographed overnight at $70^{\circ} \mathrm{C}$. All chemical reagents were purchased from Sigma Diagnostics, St Louis, Missouri, USA.

\section{Results}

The results are presented in tables 2 and 3 . As can be seen from table 3, the number of mycobacteria positive results increased from $30 \%$ on staining to $60 \%$ on culture and rose substantially to $85 \%$ on PCR and Southern blotting.

Of the 17 PCR positive specimens, six (35\%) were culture positive only, and more importantly, five were negative when cultured or stained. All PCR negative samples were also negative when cultured or stained. No false negative results were observed and all controls gave the expected results.

\section{Discussion}

Concurrent with the AIDS epidemic, there has been a notable increase in the incidence of tuberculosis. ${ }^{5-7}$ This increase in incidence results partly from the emergence of multiresistant strains and the evolution of diagnostic techniques, PCR being one example. PCR has been used repeatedly for detecting mycobacteria in sputum, ${ }^{8}$ cerebrospinal fluid ${ }^{9}$ and stool samples. ${ }^{10}$ It has been used to increase diagnostic sensitivity, ${ }^{11}$ to improve treatment by controlling resistance phenomena $a^{12-14}$ and to facilitate characterisation of different $M$ tuberculosis strains. ${ }^{15}$

Mycobacterial infection is notoriously difficult to diagnose on staining. In the present study the percentage of positive results on staining was very low compared with conventional culture in Lowenstein-Jensen medium, which in turn was not as sensitive as the PCR method. We were unable to compare our 
results on skin samples with those of other authors, but we could compare results on other sample types-for example, pleural, bronchial, sputum. Schijman et al ${ }^{16}$ detected mycobacterial DNA in $34 \%$ of samples; in the study by Kiehlbauch et al $^{17} 14 \%$ of samples were PCR positive but not all patients included in that study were thought to have mycobacterial infection. In spite of this, PCR was more sensitive than the conventional methods. Of the 20 skin lesions studied here, $29 \%$ were PCR positive but negative when stained or cultured. We consider these PCR positive results to be of great importance. With the advent of the AIDS epidemic the number of patients presenting with extrapulmonary tuberculosis is increasing. If a diagnosis of tuberculosis is suspected, but staining and culture are inconclusive, it is advisable either to increase the length of time specimens spend in culture or to search for mycobacterial DNA using PCR. In the PCR method described here, the specificity of the amplification reaction was confirmed by subjecting an aliquot of the PCR product to agarose gel electrophoresis followed by Southern blotting. The latter can also be used to characterise the strain present. ${ }^{18} 19$ This method facilitates diagnosis of extrapulmonary tuberculosis and can be used readily in the routine diagnostic laboratory. ${ }^{20}$

1 Cabeza F, Ebri B, Simal E. Absceso subcutáneo tuberculoso de la pared torácica por diseminación hematógena. Rev Esp Microb 1990;5:446-8.

2 Wilkinson D. Tuberculosis of the skin. Textbook of dermatology. 3rd edn. Oxford: Blackwell Scientific, 1979:667-99.

3 Beyt B, Ortbals D, Santa Cruz D, Kobayashi G, Eisen A Medof G. Cutaneous mycobacteriosis: analysis of 34 cases with a new classification of the disease. Medicine 1980;60 95-109.

4 Altamirano M, Kelly MT, Wong A, Bessuille E, Black W, Smith J. Characterization of a DNA probe for detection of $M$ tuberculosis complex in clinical samples by PCR. $\mathcal{F}$ Clin Microbiol 1992;30:2173-6.
5 Gachot B, Wolff M, Clair B, Regnier B. Severe tuberculosis in patients with human immunodeficiency virus infection. Intesive Care Med 1990;16:491-3.

6 March Ayuela P, García González A. La evolución de la infección VIH/SIDA en los paises desarrollados. Impacto sobre la Tuberculosis. Med Clin (Barc) 1993;100:187-93.

7 Vadillo M, Corbella X, Carratala J. AIDS presenting as septic shock caused by Mycobacterium tuberculosis. Scand $\mathcal{f}$ tic shock caused by Myco

Infect Dis 1994;26:105-6.
Shawar RM, El-Zaatari F, Nataraj A, Clarridge J 3d. Detection of Mycobacterium tuberculosis in clinical samples by wo-step polymerase chain reaction and non isotopic hybridization methods. 7 Clin Microbiol 1993;31:61-5.

9 Palittapongarnpin P, Rienthong S, Panbangred W. Comparison of restriction fragment length polymorphism of Mycobacterium tuberculosis isolated from cerebrospinal fluid and sputum: a preliminary report. Tuber Lung Dis 1993;74:204-7.

10 Guillou J, Henault S, Ostyn A, Thorel M. Use of the in vitro enzymatic amplification method for the detection of Mycobacterium paratuberculosis in feces. Rev Sci Tech 1993;12: 605-15.

11 Reddi P, Talwor G, Khandekar P. Molecular cloning and characterization of contiguously located repetitive and single copy DNA sequences of Mycobacterium tuberculosis: development of PCR based diagnostic assay. Int $\mathcal{f}$ Lepr Mycob Dis 1993;61:227-35.

12 Rastogi N, Ross B, Dwyer B, Goh K, Clavel S, Jeantils V Cruaud P. Emergence during unsuccessful chemotherapy Cruaud $P$. Emergence during unsuccessful chemotherapy tuberculosis. Eur ₹ Clin Microb Infect Dis 1992;11:901-7.

13 Zhang Y, Heym B, Allen B, Young D, Cole S. The catalaseperoxidase gene and isoniazid resistance of Mycobacterium tuberculosis. Nature 1992;358:591-3.

14 Zhang Y. Genetic basis of isoniacid resistance of Mycobacterium tuberculosis. Rev Microbiol 1993;144:143-9.

15 Yven L, Ross B, Jackson K, Dwyer B. Characterization of Mycobacterium tuberculosis strains from Vietnamese patients by Southern blot hybridization. 7 Clin Microbiol 1993;31:1615-17.

16 Schijman A, Smayevsky J, Weltman G, Lasso M, Saenz G, Hoffman $M$, et al. Rapid diagnosis of tuberculosis by polymerase chain reaction (PCR) in a clinical laboratory from Buenos Aires, Argentina [abstract]. The 94th General Meeting of ASM. Las Vegas; 1994. Washington, DC: ASM 1994:186.

17 Kiehlbauch J, Marowski J, Wisniewski T, Bowles E, Banker $\mathrm{O}$, Fonta $\mathrm{K}$, et al. Ability of PCR, Bacte, septichek and conventional media to detect Mycobacteria in clinical specimens Las Vegas; 1994. Washington, DC: ASM, 1994:185.

18 Lebrun L, Martin C, Vicent V. Tubercle bacilli identifica tion with nucleic acid probe. Lancet 1993;341:1486.

19 Hadalo C, Campbell S, Edberg S. Assessment of PCR for the routine clinical diagnosis of tuberculosis [abstract]. The 94th General Meeting of ASM. Las Vegas; 1994. Washing ton, DC: ASM, 1994:186.

20 Clarridge JE 3d, Shawar R, Shinnick T. Large scale of polymerase chain reaction for detection of Mycobacterium tuberculosis in a routine mycobacteriology laboratory. $\mathcal{F}$ Clin Microbiol 1993;31:2049-51. 